\title{
Inheritance tax - an equitable tax no longer: time for abolition?
}

\author{
Natalie Lee* \\ Professor of Law, University of Southampton
}

Statistics from HM Revenue \& Customs predict that receipts from inheritance tax will amount to some $£ 3.56$ billion in the tax year 2006/07. This compares to $£ 1.68$ billion in 1997/98. This paper explores the reason for the large increase in inheritance tax revenues and, in the light of those findings, together with a consideration of the recent public reaction to the changes to the inheritance taxation of trusts announced in the Budget 2006 and incorporated in the Finance Act 2006, argues that, whereas the justification for a tax on the value of property in a person's estate on death (or within a certain number of years before death) was rooted in equity, equity now forms the argument for its abolition or, at least, its substantial reform.

\section{INTRODUCTION}

Despite a promise by the last Conservative Government that it would abolish inheritance tax when it could afford to do so, ${ }^{1}$ there has been little suggestion from either the current opposition or the government that this is likely to happen. ${ }^{2}$ The unwillingness of any of the political parties to consider the abolition of inheritance tax (IHT), despite its demise in other jurisdictions, most notably Canada, Australia and, more recently, Sweden, ${ }^{3}$ is probably based on the notion that some form of inheritance

* My thanks to the helpful comments made by Professors John Prebble, University of Wellington, New Zealand and John Tiley, Queens' College, Cambridge and Timothy Vollans, University of Coventry, during the presentation of an earlier form of this paper at the conference of the Society of Legal Scholars, Keele, September 2006, and to the anonymous referees for further comments. Any remaining errors are, of course, my own.

1. Chancellor of the Exchequer, the Rt Hon Kenneth Clarke MP, Budget speech, Hansard HC Deb, vol 286, col 169, 26 November 1996.

2. In Inheritance Tax: A New Direction (December 2004), the third in a series of Conservative Party consultation documents entitled 'Towards a Lower Tax Economy', five possible options for making inheritance tax fairer and simpler were canvassed, including its abolition. It is clear from the brevity with which that option was discussed that it was not the favoured one. And despite the finding of the report of the Conservative's Tax Reform Commission (Tax Matters: Reforming the Tax System (19 October, 2006)), chaired by former Conservative Government Cabinet Minister, Lord Forsyth, that inheritance tax should be abolished, it appears that David Cameron, current leader of the Conservative Party, has ruled out immediate tax cuts (should his party come to power). It is quite clear that such tax reforms as there might be, are likely to affect the business sector rather than the personal one (Daily Telegraph 20 October 2006). This approach follows a previous report that the Conservatives, whilst currently looking at ways of easing the burden of inheritance tax, including the possibility of exempting a deceased person's main home from the $40 \%$ levy, have ruled out any early move for its abolition (Daily Telegraph 23 August 2006).

3. Whilst New Zealand abolished its estate duty, its gift tax remains in place. It should be noted that Italy too has abolished its estates tax. 
or estates tax is essential for the purpose of distributive justice. ${ }^{4}$ According to this theory, the tax serves the equitable purpose of contributing towards a redistribution of wealth by placing liability on those who have wealth above a given threshold ${ }^{5}$ and who are thus better able to pay the tax than others. This satisfies Adam Smith's first canon for a fair system of taxation, namely equity between taxpayers, about which he wrote: "the subjects of every state ought to contribute towards the support of the government as nearly as possible in proportion to their respective abilities; that is in proportion to the revenue which they respectively enjoy under the protection of the state'. ${ }^{6}$

However, much of a person's estate will already have been subject to tax at least once during their lifetime, real property prices (certainly in London and the South East) have escalated in recent years, thereby eating into, if not far exceeding, the nil rate band, ${ }^{7}$ and the very wealthy are able to avoid paying inheritance by distributing large amounts of their wealth free of IHT during their lifetime, ${ }^{8}$ leaving the burden to fall on those with moderate wealth only. It should be noted at this point that it is impossible to give any definition of the term 'wealthy' and thus also of 'very wealthy'. As Rubenstein has written, "wealth" has only a relative meaning and denotes considerably different levels of riches at different times'. ${ }^{9}$ Thus, a person who 5 years ago owned a modest semi-detached house worth $£ 175,000$, and who would not have been subject to IHT on that amount had he or she died at that time, will find that the self-same property in March 2007 is worth $£ 288,400$, and above the IHT threshold of $£ 285,000$ in place at that time. This increase in the value of his or her property due to inflation has not miraculously made the individual 'wealthy'; his or her relative wealth remains the same..$^{10}$ Moreover, whilst Adam Smith advocated equity between taxpayers, he was also of the view that '[A]ll taxes upon the transference of property of every kind, so far as they diminish the capital value of that property, tend to diminish the funds destined for the maintenance of productive labour'. ${ }^{11}$ In view of all of this, it is reasonable to ask whether IHT is now quite as equitable as it is made

4. See, eg, J Rawls A Theory of Justice (Cambridge MA: Harvard University Press, revised edn, 1999) particularly pp 245-251; JE Meade Efficiency, Equality and the Ownership of Property (London: George Allen and Unwin, 1964) pp 56ff; L Murphy and T Nagel The Myth of Ownership: Taxes and Justice (New York: Oxford University Press, 2002) ch 7.

5. Up to that threshold ( $£ 300,000$ for the tax year 2007/08), the estate is subject to the "nil rate band'.

6. A Smith (1776) The Wealth of Nations vol II (London: Methuen, Cannan edn, 1950) p 185.

7. See above $\mathrm{n} 5$.

8. By means of potentially exempt transfers (PETs); see below. The very wealthy are able to do this and retain sufficient wealth for their own purposes.

9. WD Rubenstein Men of Property - The Very Wealthy in Britain since the Industrial Revolution (London: The Social Affairs Unit, 2006) p 39.

10. These figures are based on a comparison of Rightmove's first published index of residential property prices in August 2002 (www.rightmove.co.uk/pdf/p/hpi/RealTimePropertyReport 20August2002.pdf), when the average house price was £147, 957, with that in March 2007 (www.rightmove.co.uk/pdf/p/hpi/HousePriceIndex19March2007), when it was £228,183. This shows a $64.8 \%$ increase in house prices in under 5 years. In contrast, the IHT threshold during that same period rose by only $14 \%$ ( $£ 250,000$ in $2002 / 03$, and $£ 285,000$ in $2006 / 07$ ). The problem is even greater in particular 'hotspots' such as Winchester, where it is reported that the average cost of a home in the city council area is £330, 452 compared to £228,183 nationally (www.rightmove.co.uk/pdf/p/hpi/HousePriceIndex19March2007).

11. See above n 6, p 224. 
out to be. To this debate must be added the provisions contained in the Finance Act 2006, which have the effect of withdrawing future IHT relief from certain types of trust. These provisions, which are believed to affect far greater numbers of taxpayers than simply the very wealthy at whom they were allegedly directed, and the method of their introduction, both discussed below, enraged tax practitioners and those reportedly large numbers of the public who had planned for the future through the use of these trusts.

In light of the mounting criticism of IHT by the public, ${ }^{12}$ the aim of this paper is to establish the equity criteria upon which an inheritance or capital estates tax is (or should be) founded, and then to consider whether the retention of our current system can be justified. It is possible that substantial reform could provide an answer to the charge that IHT is currently unfair, but if, additionally, the system is economically inefficient, then abolition may be the correct solution. In any event, the point should be made at this juncture that this author is not arguing against death being a taxable event, since this argument could be countered by the introduction of a regime taxing lifetime gifts and a partial return to the days of capital transfer tax which, as will be described, were not happy ones. The argument is that there should be no tax on the transfer of wealth. This then leaves open the possibility of restoring the capital gains tax charge (CGT) on death; CGT is currently charged on the increase in value of a capital asset between the time of its acquisition and of its disposal, but only where the disposal occurs during the lifetime of the owner. Although a full debate on that issue is outside the scope of this paper, a few observations on the implications attendant to the reintroduction of a CGT charge on death are made later.

The argument for the abolition of IHT has already been made with some considerable force, ${ }^{13}$ but it has been commented that the argument was not, and did not pretend to be, a balanced account of the subject. ${ }^{14}$ This review attempts a fair evaluation of all the arguments. The paper will start with a brief historical review of death duties in the UK and an introduction to IHT, followed by a consideration of the perceived injustice of the tax, weighed against arguments based in equity (the modern justification for taxing the transfer of wealth on death) and the economic arguments for its retention. Historical comparisons will be made, along with an analysis of the reasons behind the abolition of the estates tax in Australia, Canada and Sweden.

\section{THE HISTORY OF IHT $^{15}$}

A distinction should be drawn between mutation duties and accessions taxes. ${ }^{16}$ The first are usually charged at progressive rates on the value of property transferred by

12. See, eg, The Observer campaign for the abolition of IHT conducted in 2005-06, and below $\mathrm{n} 90$.

13. See B Bracewell-Milnes Euthanasia for Death Duties: Putting Inheritance Tax Out of its Misery (London: Institute of Economic Affairs, 2002). See also B Bracewell-Milnes Free Wills: Inheritance Without Taxation (London: Adam Smith Institute, 1995).

14. J Tiley [2003] 3 BTR 255-256.

15. For a brief historical review of estate taxes up to CTT, see J Tiley Beattie's Elements of Estate Duty (London: Butterworths, 1974) pp 1-6. For a review that includes CTT, see J Coombes Capital Transfer Tax (London: Professional Books, 1977) pp 1-9; M Hepker and C Whitehouse Capital Transfer Tax (London: Heinemann, 1975) pp 9-18.

16. Called inheritance taxes when confined to transfers on death. 
donors, either during their lifetime or on their death. In contrast, accessions taxes are those which are charged by reference to the value of the benefit received by the donee, and whose rates and exemptions are governed by his or her circumstances rather than by those of the donor. In spite of the fact that an accessions tax may seem fairer, and would appear to encourage donors to spread their wealth more widely amongst people who have received few inheritances and who would, accordingly, be liable to either no tax at all or to less tax, the UK has generally opted for mutation duties in the form of probate duty, ${ }^{17}$ account duty, ${ }^{18}$ temporary estate duty, ${ }^{19}$ estate duty, ${ }^{20}$ settlement estate duty, ${ }^{21}$ capital transfer tax ${ }^{22}$ and, despite the misnomer (for it would seem to imply an accessions duty), IHT. In contrast, legacy duty ${ }^{23}$ fell on the amount received by each individual beneficiary, and the amount charged depended on their relationship with the deceased and, by definition, succession duty ${ }^{24}$ also took account of the recipient of the estate.

The introduction of estate duty in 1894 came at a time of growing importance of death duties, with a move away from taxes on consumption to direct taxes on income and wealth. ${ }^{25}$ And their importance did not simply rest in a relatively high yield; it is the view of one economic historian that "death duties operated as a "balance" in order to create a sense of equity and fairness in the income tax ... Graduated taxation of estates at death was more easily accepted than graduation of income tax . . ${ }^{26}$ This is not difficult to comprehend. The Victorian era witnessed a growth in 'new money' from trade and industry, and those who worked hard to make their wealth naturally resented being taxed on the income that they earned, whilst the owners of 'old

17. A stamp tax, introduced in 1694 , and repealed in 1894 .

18. Introduced in 1881 to prevent the avoidance of probate duty by the making of lifetime gifts, and repealed in 1984 .

19. Introduced in 1889 and repealed in 1894; this was supplementary to probate, succession and account duties.

20. Introduced in 1894, and repealed in 1975 .

21. Introduced alongside estate duty in 1894 to compensate for the fact that, in relation to settlements, estate duty could only be levied on the first death. It was repealed in 1914, when estate duty on settled property was extended to deaths subsequent to the first death.

22. Although the law was not enacted until 13 March 1975, it was retrospective to 27 March 1974 in respect of inter vivos gifts and settled property. As pointed out by GSA Wheatcroft and GD Hewson in Capital Transfer Tax (London: Sweet \& Maxwell, 1975) p 2, '[T]he best comment on this procedure was written by Adam Smith nearly 200 years ago in 1776 when he stated his second canon of taxation as follows: "The tax which each individual is bound to pay ought to be certain and not arbitrary. The time of payment, the manner of payment, the quantity to be paid ought all to be clear and plain to the contributor, as to every other person." (The Wealth of Nations, Book 5, Chap. 11, Part II - "of taxes") None of these facts were clear and plain until the Act was passed....

23. An inheritance duty, introduced in 1780 and not repealed until 1949.

24. Another inheritance duty, introduced in 1853 and also not repealed until 1949.

25. Death duties accounted for $14 \%$ of total tax revenues in 1901 compared to $7.6 \%$ in 1871 : BR Mitchell and P Deane Abstract of Historical Statistics (Cambridge: Cambridge University Press, 1962) pp 393-394. For 2006/07, it is estimated that IHT will account for $0.8 \%$ of total tax revenues: HMRC Annual Receipts T1.2 (updated to December 2006).

26. M Daunton Trusting Leviathan: The Politics of Taxation in Britain 1799-1914 (Cambridge: Cambridge University Press, 2001) p 225. See also C Sandford Taxing Inheritance and Capital Gains: Towards a Comprehensive System of Capital Taxation (London: The Institute of Economic Affairs, 1967) pp 13-14; C Sandford Taxing Personal Wealth (London: George Allen \& Unwin, 1971) pp 73-74. 
money', who had inherited their wealth and enjoyed a life of leisure, bore no income tax on the fruits of their property at all. In effect, death duties sought to redress the balance. And yet, interestingly, prior to 1894, real property, which formed the basis of serious wealth at the time, was either fully exempt from duty ${ }^{27}$ or charged at a lesser rate than personal property. ${ }^{28}$ There was much debate in the period prior to the reform of death duties in 1894 about how to tax land. First, there were those like Charles Fox who opposed the taxation of land at all for fear of a confiscation by the state of all capital. Secondly, whilst Gladstone and his followers believed that real property should be subject to death duties, they felt that, given the additional burdens on land from local taxation or rates, it was correct to set a lower rate for such property. Finally, there was an emerging view that those who owned land enjoyed an increase in its value due to the initiative of traders and industrialists, in the words of Martin Daunton, a 'socially created' increase ${ }^{29}$ and, accordingly, the community should recoup the value for itself through the imposition of a much higher tax on land. The partial outcome of this debate was the introduction, in 1894, of estate duty, which sought to tax the value of property passing under a will or intestacy and to gifts made within a period before death, ${ }^{30}$ including real property.

The belief was that this new and graduated tax would both increase the yield from death duties and appear to be a fair attempt to impose tax on those better able to pay. However, whilst it was perceived to be an equitable tax, it was described by Roy Jenkins, a former Chancellor of the Exchequer, as 'a voluntary levy paid by those who distrust their heirs more than they dislike the Inland Revenue'. ${ }^{31}$ Estate duty was said to favour the healthy, wealthy and well advised since, with a certain amount of foresight and planning, it could be avoided, or at least substantially reduced, with apparent ease by someone giving away capital and surviving the statutory period.

It was for this reason that, in 1972, the Conservative Government set about considering possible alternatives to estate duty, ${ }^{32}$ one of these being an accessions tax. Three features of an accessions tax distinguish it from estate duty and the misnamed IHT currently in force in the UK. First, and as its name suggests, it looks to the donee rather than to the donor, and thus is a tax on what is received by the heirs, irrespective of the size of the estate from which the inheritance comes. Because of this, the argument is that an accessions tax has far greater flexibility than estate duty or IHT in achieving equity, since it can take account of the relationship of the heirs to the deceased. Moreover, it is believed to have a far greater effect on reducing wealth inequality because it encourages the testator to spread his or her wealth more widely among a greater number of beneficiaries. Secondly, it embraces not only inheritances but also lifetime gifts. This, it is said, keeps tax avoidance to a minimum. Thirdly, it is (or can be) cumulative over a donee's lifetime, again reducing the incidence of tax

27. Despite the fact that, in 1796, it was William Pitt's intention to include real property within legacy duty, he withdrew the measure. However, succession duty did charge land after 1853.

28. As with succession duty. For an analysis and a concise review of death duties, see Daunton, above $\mathrm{n} 26$, ch 8 .

29. Ibid, p 238.

30. At the time of its repeal in 1975 , this period was 7 years.

31. Budget Debate Hansard HC Deb, vol 94, col 325, 19 March 1986. Admittedly, Roy Jenkins was arguing against the demise of CTT and the reinstatement of death duties, rather than advocating the general abolition of tax on a transfer of wealth.

32. See the Green Paper Taxation of Capital on Death: A Possible Inheritance Tax in Place of Estate Duty Cmnd 4930, March 1972. 
avoidance and, with a view to minimising the tax that will be paid by the recipients, encouraging testators to spread their wealth more widely. ${ }^{33}$ Despite the clear indication that an accessions tax could go some way to reducing wealth inequality, it was admitted at the time that it would be far more costly than estate duty for both administrative and compliance purposes. ${ }^{34}$ In any event, the Conservatives did not get the chance to adopt any of the alternatives, losing power to Labour in 1974.

It was with the Labour Government that change finally came in 1975, when capital transfer tax (CTT) was introduced..$^{35}$ Although the government had been committed to an IHT properly so called, looking at what a donee receives rather than at what the donor gives, the Inland Revenue made it clear that they were unprepared to administer such a system. Accordingly, CTT was charged with reference to the estate of the donor, in the same way that estate duty had been. However, apart from that, there were important differences between the two taxes. CTT, for the first time in UK history, brought together a tax on death and a tax on all lifetime gifts, and not just those made within a stated period before death. The system was cumulative, so that the amount of tax paid on a lifetime gift, or indeed upon the death of the donor, depended upon all gifts previously made, and the rates were progressive. Discretionary trusts were subject to a much harsher regime than were trusts with interests in possession, although some relief was found in the accumulation and maintenance (A\&M) trust. ${ }^{36}$ It was thought that, as a result of the introduction of CTT, a number of wealthy people decided to move abroad taking with them as much of their capital as possible, ${ }^{37}$ and yet the man who introduced it, Denis Healey, the then Chancellor of the Exchequer, did not believe that it was having a serious impact. Of the tax he has written:

'I replaced the Estate Duty, which had become a laughing stock, since no one who could afford an accountant ever paid it, with a Capital Transfer Tax which covered gifts made before death as well. From the start I excluded money inherited by a man's widow from the Tax. This piece of natural justice was long overdue; I still meet people who thank me for it. But in the end, I had to accept so many other special cases for exclusion that when I left office four years later, the CTT was still raising less revenue than the avoidable Estate Duty it replaced. ${ }^{38}$

33. It is interesting to note that, although Ireland has an acquisitions tax, capturing both lifetime gifts and bequests, cumulation is for periods only rather than for lifetime. The periods are not fixed and come to an end when the government decides that they should. I am indebted to Anne Corrigan, barrister and senior associate at Arthur Cox, Dublin, for providing this information in the course of a Tax Law Workshop held at Queens' College, Cambridge on 27 April, 2007.

34. This was admitted by Cedric Sandford et al even though they were otherwise completely in favour of an accessions tax: CT Sanford, JRM Willis and DJ Ironside An Accessions Tax IFS Publications No 7 (September 1973). It was this issue that defeated the intention of the Labour Government in 1975 to introduce CTT as an accessions tax; see further below.

35. The original provisions were to be found in the Finance Act 1975, but were consolidated in the Capital Transfer Tax Act 1984.

36. This was a favoured trust in that it enabled a settlor to establish what was, in effect, a discretionary trust for the benefit of minors, but which was not subject to the discretionary trust regime provided that the beneficiary or beneficiaries would become entitled to the trust property or to an interest in it by the age of 25 . This is discussed further below.

37. For an apocryphal tale illustrative of the economic consequences of CTT, see Wheatcroft and Hewson, above n 22, pp 12-13.

38. D Healey The Time of My Life (London: Michael Joseph, 1989) p 404. 
Apart from the spouse exemption, the other exclusions to which Denis Healey referred include relief for agricultural property ${ }^{39}$ and, for transfers occurring after 6 April 1976, relief for business property. ${ }^{40}$ Without these reliefs, the burden of tax on the high capital value of a farmer's main asset and of business assets respectively would probably have necessitated a sale of the property to enable the tax to be paid. A measure of relief was also given in respect of gifts to charities in that the first $£ 100,000$ was exempt insofar as they were made on, or within 1 year of, death; ${ }^{41} 8$ years later, all gifts to charities became exempt without limit. ${ }^{42}$ Exempting from CTT an individual's main residence was never considered; at that time, home ownership was less widespread than it is now and, as it has just been shown, the then Chancellor of the Exchequer believed that he had conceded more than enough exemptions and reliefs.

These exemptions aside, the simple explanation for the low yield, of course, might have been that too many wealthy people had fled the country taking their wealth with them. Indeed, in a book written at the time of the introduction of CTT, one author wrote that 'the next Chapter does contain some useful hints for survival. Readers may find it repays study even if they are at this stage tempted to jump straight to the Chapter 14 on emigration', ${ }^{43}$

Following an earlier substantial amendment by a new Conservative Government, dismantling the system of lifetime cumulation, ${ }^{44}$ in 1986 the Capital Transfer Tax Act 1984 became the Inheritance Tax Act $1984 .{ }^{45}$ In effect, this Act brought an end to the taxation of lifetime gifts. The current IHT system, built upon the changes made by the Finance Act 1986, is outlined below.

\section{A BRIEF OUTLINE OF THE CURRENT SYSTEM OF IHT}

IHT is charged at the apparently quite high rate of $40 \%{ }^{46}$ on the value, in excess of $£ 300,000,{ }^{47}$ of a person's estate immediately before his death, ${ }^{48}$ and this value includes

39. By virtue of Finance Act 1975, s 35 and Sch 8 as amended by Finance Act 1976, s 74, agricultural property which was the subject of a chargeable transfer and where it passed on death, was given a concessionary lower value.

40. Finance Act 1976, s 73 and Sch 10. Business property relief, which was introduced for CTT purposes only one year after the passing of the original Act, was given by reducing the value (by 50\%) of business property passing by way of a chargeable transfer, subject to a cumulative limit of $£ 500,000$.

41. Finance Act 1975 , s 29 and Sch 6 , para 10 . This limit was raised to $£ 200,000$ by Finance Act 1980, s 86, and to $£ 250,000$ by Finance Act 1982, s 92.

42. Finance (No 2) Act 1983, s 9.

43. J Chown A Guide to Capital Transfer Tax (London: Kogan Page, 1975) p 128. As taxation correspondent of the Financial Times, head of his own international tax consultancy firm and co-founder of the Institute for Fiscal Studies, John Chown was able to speak with some authority on the matter.

44. Finance Act 1981, s 93.

45. By virtue of Finance Act 1986, s 100(1)(2).

46. Inheritance Tax Act (IHTA) 1984, s 7 and Sch 1. The UK, along with France, has the fourth highest top estate tax rate out of 50 countries surveyed by PricewaterhouseCoopers in 2005. Half of these countries had abolished the duty, and the average rate amongst the 50 was 13\%: New International Survey Shows US Death Tax Rate among Highest (American Council for Capital Formation, July 2005); C Edwards Repealing the Federal Estate Tax Tax \& Budget Bulletin, No 36 (Cato Institute, June 2006).

47. For the tax year $2007 / 08$. The value up to the threshold is known as the nil rate band.

48. IHTA 1984, s 4. 
any lifetime gifts made within 7 years of death. ${ }^{49}$ Outright gifts to individuals made during a donor's lifetime are potentially exempt, and only become liable to IHT if the donor dies within 7 years of making the gift. ${ }^{50}$ It is through sensible use of the nil rate band and the making of potentially exempt transfers (PETs) that the very wealthy, who can afford to give away large portions of their wealth whilst still retaining sufficient to maintain a high standard of living, are able to minimise IHT. There also exist important exemptions, most of which have been carried over from CTT. Thus, both lifetime transfers and gifts on death between spouses and civil partners ${ }^{51}$ are exempt, ${ }^{52}$ and, although it has been argued that they tend to promote avoidance rather than enterprise, ${ }^{53}$ the reliefs with respect to business ${ }^{54}$ and farming ${ }^{55}$ property that seek to ensure that those who inherit such property do not have to sell it in order to pay the tax are enhanced. Heritage property is also afforded relief in various different forms. ${ }^{56}$ In addition, there is an annual exemption of $£ 3000$ per person, ${ }^{57}$ which grand sum has remained the same since 1984 (when it applied for CTT purposes) ${ }^{58}$ and, if this amount is not used in any 1 year, the unused amount may be utilised in the following year, but in that year only; if it is not used then, it is lost.

As far as gifts in trust are concerned, prior to 22 March 2006, there existed two regimes. The first applied to trusts with an interest in possession. An interest in possession is said to exist where a beneficiary (or beneficiaries) have an immediate right to receive the income arising from the trust (if any).$^{59}$ The inter vivos transfer of property into this type of trust was a PET and would remain exempt on the donor surviving for 7 years. Moreover, for IHT purposes, a beneficiary of an interest in possession trust was treated as owning the capital in which the interest subsisted and, on his death, the value of that capital was added to his free estate. ${ }^{60}$ The rationale behind this was that, although a beneficiary could not have actually acquired the

49. Ibid, s 3A (4)(5).

50. Ibid.

51. The Civil Partnership Act 2004, which came into force on 5 December 2005, gave samesex couples in the UK the opportunity of acquiring a legal status for their relationship, thus enabling them to gain rights and responsibilities that mirror those available to a married couple. Although taxation measures were not provided for in the Act itself, the Finance Act 2005, s 103 enables the Treasury to make regulations (see Tax and Civil Partnership Regulations 2005, SI 2005/3229) providing similar treatment for civil partners and civil partnerships as is given to married persons and marriage. The effect of this means that, from 5 December 2005, tax charges and reliefs have applied to civil partners and married couples alike.

52. IHTA 1984, s 18.

53. C Sandford Successful Tax Reform - Lessons from an Analysis of Tax Reform in Six Countries (Bath: Fiscal Publications, 1993) p 46.

54. IHTA 1984, ss 103-114.

55. Ibid, ss $115-124 \mathrm{C}$.

56. For example, gifts for national purposes (IHTA 1984, s 25), maintenance funds for historic buildings (IHTA 1984, s 27) and conditional exemption for property of national, scientific, historic or artistic interest (IHTA 1984, ss 30-42).

57. IHTA 1984, s 19.

58. Capital Transfer Tax Act 1984, s 19.

59. For a full discussion of the meaning of this important term, which is not statutorily defined, see Pearson v IRC [1980] 2 All ER 479. Although this case concerned CTT, the same principles apply to IHT.

60. IHTA 1984, s 49. 
capital of the trust, he had enjoyed the economic benefit of it during his lifetime and, accordingly, the value of that capital was a proper subject for taxation on his death. Should a beneficiary have disposed of his interest during his life, or should the interest have terminated for any other reason, such a termination would generally have been a PET, and would have escaped a charge to IHT on the beneficiary surviving 7 years.

The second regime, known as the 'relevant property' regime, applied to trusts where there existed no interest in possession. This category, which was, and continues to be, subject to a much harsher set of rules, very loosely comprised, prior to the 2006 changes, discretionary trusts. The transfer of property by the settlor into such a trust was, and continues to be, a chargeable transfer, resulting in an immediate IHT charge of $20 \% .^{61}$ This charge applies where the value of the transfer, in addition to any other chargeable transfers made within the previous 10 years, exceeds $£ 300,000$. The trust also incurs periodic charges throughout its life through the imposition of an anniversary charge on its value every 10 years from its inception. ${ }^{62}$ Moreover, a further charge is incurred when an object of the discretion becomes entitled to the trust property, or to an interest in it. ${ }^{63}$ An exemption from this second regime was given to A\&M trusts, which enjoyed favourable status. ${ }^{64}$ This type of trust enabled a settlor to establish a trust for the benefit of minors, with no interest in possession existing until the minor was at least 18, with the income in the meantime being accumulated. Provided that a beneficiary would become entitled to the trust property, or to an interest in it, by the age of 25 , the creation of the A\&M trust was a PET, ${ }^{65}$ there was no 10 -year anniversary charge,$^{66}$ and no exit charges were incurred when the beneficiary became entitled to the income and/or to the trust capital. ${ }^{67}$

An important anti-avoidance provision is that which prevents a person from making a gift (outright or into trust) and then reserving a benefit in the gifted property. ${ }^{68}$ It is this piece of legislation that, for example, restricts the owner of real property from giving away his freehold or leasehold interest during his life to, say, his children, and continuing to live in it thereafter. There have been a number of elaborate attempts to circumvent this provision, and whilst the courts have upheld some of these attempts ${ }^{69}$ legislation has subsequently reversed the effect of these decisions. ${ }^{70}$ Moreover, for those taxpayers who continue successfully to circumvent the reservation of benefit rules, there is now imposed an annual income tax charge where the donor enjoys the benefits of pre-owned assets. ${ }^{71}$ The provisions relating to this charge are excessively complicated, causing additional administrative and compliance costs, and

61. Ibid, ss 3, 3A and 7(2).

62. Ibid, ss 61 and 64 .

63. Ibid, s 65 .

64. Ibid, $\mathrm{s} 71$.

65. Ibid, s $3 \mathrm{~A}(1)$ and (3).

66. Because the property was prevented from being 'relevant property'.

67. IHTA 1984, ss 71(4) and 53(2).

68. Finance Act 1976, s 102.

69. See, eg, Ingram v IRC [2000] 1 AC 193; IRC v Eversden [2003] EWCA Civ 668, [2003] STC 822 .

70. See Finance Act 1986, ss 102A-C, inserted by Finance Act 1999, s 104, reversing the effect of the Ingram judgment; Finance Act 1986, s 102(5), (5A)-(5C), inserted by Finance Act 2003, s 185, reversing the effect of Eversden.

71. The chargeable amount for any taxable period is the appropriate rental value less any payments made by the chargeable person in respect of the relevant land or chattels (Finance Act 2004, s 84 and Sch 15). 
represent a further blow to those who, unlike the very wealthy, cannot afford to give away their property in advance of death in order to minimise their IHT bill, and who seek other ways in which to achieve the same fiscal result. This problem was referred to as long ago as 1975 in relation to estate duty, when it was said that 'few of the estate duty "loopholes" could effectively be used to any substantial extent by people with moderate wealth' ${ }^{72}$ Cedric Sandford similarly commented that 'the wealthiest can afford the best advice on IHT "mitigation" and are also best placed to make gifts early (ie outside the period of seven years before death) and so tax free'. ${ }^{73}$ More recently, Lord Newby, a Liberal Democrat, expressed the view that 'we are in a highly unsatisfactory situation in which the very rich can avoid IHT altogether by careful planning, whereas the merely affluent are increasingly being caught by it' ${ }^{74}$

\section{THE 2006 MEASURES}

The provisions contained in the Finance Act 2006 were originally announced in a press release by HM Revenue and Customs (HMRC) at the time of the 2006 Budget $^{75}$ but, interestingly, were omitted from the speech itself, as well as from the consultation that had been taking place over the previous 2 years on the question of reform of the taxation of trusts. They have the effect of withdrawing IHT benefits from both interest in possession trusts and A\&M trusts. Although the Budget contained a plethora of important and far-reaching proposed tax measures ${ }^{76}$ from the amount of correspondence in the quality newspapers on the issue, it was the IHT changes that appeared to capture the attention of a public usually immune to the finer points of the Chancellor of the Exchequer's March announcements. This measure was seen to represent a wholesale reform of the inheritance taxation of trusts, sweeping away the privileges previously afforded to A\&M trusts, provisions that Denis Healey ${ }^{77}$ had been forced to introduce into the new CTT legislation to appease a broad section of the House of Commons. In light of his famous comment (if contested) that he intended to squeeze the rich through taxation 'until the pips squeaked' ${ }^{78}$ this was not an insignificant victory for his opponents. The 2006 measures were also seen as, in effect, a reversal of a part of Margaret Thatcher's attempt at drawing the teeth from CTT by potentially exempting from a charge to tax lifetime gifts into trusts with an interest in possession. ${ }^{79}$ Although the government, in the form of the Paymaster General, responded to

72. Wheatcroft and Hewson, above $\mathrm{n} 22, \mathrm{p} 8$.

73. Sandford, above $\mathrm{n} 73, \mathrm{p} 52$.

74. Hansard HL Deb, vol 684, col 470, 10 July 2006. See also the more recent comment by Lord Burnett that 'those who are very rich can afford to avoid tax, or at least most of it': Hansard HL Deb, vol 689, col 451, 1 February 2007. The case of Phizackerley $v$ Revenue \& Customs [2007] UKSPC 591, [2007] STC (SCD) 328, widely reported in the national press, is evidence of the difficulty of minimising IHT experienced by those with relatively modest means, whose 'wealth' is tied up almost exclusively in their homes.

75. BN 25.

76. See, eg, the self-contained code for real estate investment trusts.

77. The then Chancellor of the Exchequer.

78. This was something Denis Healey had reportedly said on the eve of the 1974 General Election (although no actual reports can be found) and which, according to David Smith, Sunday Times 26 March 2006, the former Chancellor has denied saying.

79. Such a gift would remain exempt provided the donor survived the gift by 7 years; see above for a detailed discussion. 
the furore against the proposed changes by claiming that these trusts are used by $1 \%$ of taxpayers only, ${ }^{80}$ they were forced to make some amendments during the passage through Parliament of the Finance (No 2) Bill. However, the amendments were limited in their effect, and were aimed primarily at preventing the retrospective effect of some of the measures; the main thrust of the new regime remains the same. What also seems to remain is the stubbornness of the government in refusing to accept that trusts in general serve a number of varying purposes and that A\&M trusts, in particular, not only minimise a possible IHT bill, but are also aimed at protecting capital funds against the possible profligacy of young people.

These changes came in hot pursuit of a package of measures designed to modernise the income and capital gains tax regime for UK trusts. Following the publication of a series of discussion papers, ${ }^{81}$ provisions were included in each of the Finance Acts 2004-2006 aimed at income and capital gains tax 'trust modernisation'. Although this was dressed up as an exercise in simplification, the main thrust behind the new provisions was to move towards a more 'tax neutral' system, in which the amount of income or capital gains tax chargeable should not vary to any great extent depending on whether the property upon which it arises is held under a trust or directly by an individual. In achieving this goal, the government sought to strike a balance between a system that does not provide artificial incentives to set up a trust, and one that avoids artificial obstacles to the use of trusts where significant non-tax benefits could be gained. Whilst HMRC originally stated that the IHT 'simplification measure' in the Finance Act 2006 was simply part of the public consultation on modernising the tax system for trusts, ${ }^{82}$ nothing in the relevant documents suggests that this was the case and, moreover, there is no mention of this measure in the Regulatory Impact Assessment for Trust Modernisation. ${ }^{83}$ Indeed, the details published in a document accompanying the Budget Statement in March $2006^{84}$ came as a complete surprise, and it was the lack of consultation that caused critics to argue that this was just another attempt by the government to raise easy money from that vast group of people who are not particularly wealthy but who, because of steeply rising property prices, nevertheless find themselves within the IHT net and who, unsurprisingly, seek to minimise the tax burden.

The new scheme for the inheritance taxation of trusts introduced by the Finance Act 2006 abandons, in effect, the classification of trusts into those with, and those without, an interest in possession. The result is that a transfer into an interest in possession trust will, on or after 22 March 2006, enjoy PET status in only two circumstances. The first is where there is a transfer into a disabled trust ${ }^{85}$ the second is where property becomes subject to a bereaved minor's trust following the death of a person who had previously enjoyed a post-death interest in possession in that

80. In a letter to The Times 24 March 2006.

81. December 2003, a subsequent consultation document ('Modernising The Tax System for Trusts', 13 August 2004) and a further discussion paper ('Discussion Paper on the Modernisation of Trusts', March 2005).

82. HMRC Guidance Note, March 2006.

83. HMRC, 8 March 2006.

84. HMRC BN 25.

85. IHTA 1984, s 3A(1A)(c)(ii). A disabled trust is one established either under the will of a deceased parent of that minor, or under the Criminal Injuries Compensation Scheme: IHTA 1984, s 71A(2); and a trust for disabled persons is defined in s 89(4)-(6) to include a person with a mental or physical disability. 
property. ${ }^{86}$ Whilst a limited range of interest in possession trusts remain subject to the regime whereby the beneficiary is treated as entitled to the property in which his interest subsists, ${ }^{87}$ all remaining trusts will be subject to the much harsher pre-22 March 2006 relevant property regime, with the exception of trusts for bereaved minors and age $18-25$ trusts ${ }^{88}$ both of which receive a measure of relief from IHT, although not the full relief previously accorded to A\&M trusts.

Given that the very wealthy are able to minimise IHT by making outright gifts that qualify as PETs and through the establishment of offshore trusts, the likelihood is that these new measures will mostly affect those with only moderate wealth, who seek ways of providing sensibly for the future of their children or grandchildren. Moreover, they will add even further complexity to a tax that has become more and more difficult to understand as the years have passed. This, of course, has repercussions for both administrative and compliance costs, which are discussed below.

\section{CURRENT PERCEPTIONS OF IHT}

In the same way that it appears to have become unthinkable in recent years for a political party, serious about winning a general election, to advance a policy of increased taxation, so it was equally unthinkable, until relatively recently, to propose abolishing IHT or any of its predecessors. However, as indicated earlier, the last Conservative Government promised to do just that when it could afford to do so $^{89}$ and, in a recently conducted poll, 73\% disputed that IHT was a 'fair way' for the government to raise money. ${ }^{90}$ The poll also revealed that $40 \%$ of those questioned had considered the impact of IHT in their own lives. Moreover, it was perhaps a surprise, that a former Labour Government minister should advocate the abolition of IHT; indeed, he came straight to the point by saying that IHT was 'a penalty on hard work, thrift and enterprise'. ${ }^{91}$ His reasons for doing so are not new and embrace some of the more 'popular' arguments in favour of abolishing IHT.

From the perception of the general public, there would appear to be three main reasons for abolishing IHT. Of course, there do exist many more arguments, some of which will be referred to in this paper, but the following three seem to be of the

86. IHTA 1984, s 3A(1A)(c)(iii). A bereaved minor is described as somebody under the age of 18 who has lost at least one parent: IHTA 1984, s 71C.

87. IHTA 1984, s 49.

88. Ibid, s 71D. An 18-25 trust operates to provide a measure of tax relief where property is held on trust for somebody who has not yet reached the age of 25 , and who has lost at least one parent: IHTA 1984, s 71D(1).

89. See above $n 1$.

90. Populus poll conducted for the BBC, March 2006. This poll concerned only IHT. See also the Telegraph YouGov poll (Daily Telegraph 23 October, 2006), where 70\% of all voters questioned favoured the abolition of IHT and the report of a survey in September 2006 showing that $75 \%$ of those surveyed thought the tax to be unfair: Guardian Unlimited, September 2006 (http://money.guardian.co.uk/print/0,329570043-120485,00.html).

91. S Byers Sunday Telegraph 20 August 2006. It could be argued that, since IHT is levied on death, it is, in reality, a penalty on the recipient of the testator's wealth, who has not worked hard for the money. However, this leaves out of account the intention of the testator/testatrix, who may very well resent that part of his or her industry will not go to the intended recipient but to the state instead. 
greatest significance. ${ }^{92}$ First, it is said that much of the property comprised in a deceased's estate has generally already been taxed once during their life and, consequently, death duties amount to double taxation. To take an example, a woman may be employed for her working life and will be charged to income tax on the earnings from her employment. She saves a certain amount of those earnings by investing one part in a building society account and another in equities. Income arises from each of these investments and will suffer income tax, albeit at different rates. ${ }^{93}$ The income that arises from her investments is then re-invested and the cycle of income taxation begins all over again. On her death, the income upon which she has been taxed now forms part of her estate, the value of which will enter the IHT computation. Is it fair that her estate may be liable to IHT in respect of property that has already suffered a charge to tax, albeit a different one? Secondly, the fact of sharply rising house prices has brought within the IHT net moderate estates, that is, estates that would previously have fallen well below the threshold, resulting in a windfall for the government. According to one source, the average cost of a property is $£ 228,183$, with that for a detached house $£ 327,068,{ }^{94}$ but the costs are much higher in certain parts of the UK. For example, the average property price in Winchester is $£ 330,452$, with that for a detached house $£ 480,999 .^{95}$ Finally, a fundamental rationale for any tax is that it is paid only by those who can most easily afford it; ${ }^{96}$ in the case of IHT, this means the very wealthy. ${ }^{97}$ More specifically, although never expressly stated, CTT was seen 'as part of the Chancellor's ${ }^{98}$ objective to reduce large individual holdings of wealth in the United Kingdom', affecting only the 'really wealthy'. ${ }^{99}$ Since, until the recent amendments, IHT was seen as being less draconian than its predecessor, there is nothing to suggest that the original policy has changed. However, because of estate planning techniques, much less of the tax actually falls on the very rich than might be expected. How valid are these arguments?

92. In other jurisdictions, those who run private businesses or who are farmers suffer particularly from an estates tax; this problem is obviated in the UK through exemptions in these particular circumstances; see IHTA 1984, ss 103-114 and ss 115-124C.

93. Savings income (excluding dividend income) is subject to income tax at the rate (for $2007 / 08$ ) of $20 \%$; dividend income is paid after deduction of income tax at $10 \%$. A basic rate taxpayer (ie somebody subject to tax at $22 \%$ (for 2007/08)) will have no further income tax to pay although a higher rate taxpayer, liable to income tax at $40 \%$ (for 2007/08), will have to pay a further $20 \%$ and $30 \%$ (the difference between $40 \%$ and the savings rate of $20 \%$ and the dividend rate of 10\%), respectively: Income and Corporation Taxes Act 1988, ss 1A and 1B.

94. See the website available at http://www.rightmove.co.uk/pdf/p/hpi/HousePriceIndex 19March2007 and see above n 10. The Financial Times House Price Index, which uses data from HM Land Registry and a statistical model to collate information from other published house price figures, shows the national average price to be $£ 213,097$.

95. See the website available at http://news.bbc.co.uk/1/shared/spl/hi/in_depth/uk_house_ prices $/ \mathrm{html} / \mathrm{houses} . \mathrm{stm}$. These figures must cast doubt over the comment made by Lord Davies of Oldham to the effect that the 'house price dimension does not stand up to close examination': Hansard HL Deb, vol 689, col 465, 1 February, 2007.

96. See above $\mathrm{n} 6$.

97. In the recent House of Lords debate on IHT, Lord Burnett said, 'I remind your Lordships that this tax and its predecessors - estate duty and capital transfer tax - were designed to be paid by the very wealthy': Hansard HL Deb, vol 689, col 451, 1 February, 2007.

98. Denis Healey.

99. Wheatcroft and Hewson, above n 22, p 8. A proposed wealth tax was another way in which it was believed that the large inequalities of wealth distribution could be addressed. 


\section{Double taxation}

As far as the argument relating to double taxation is concerned, Gale and Slemrod ${ }^{100}$ are of the view that counting the levels of tax is simply an exercise in rhetoric, and neither the facts nor the economic theory support that rhetoric. They argue first that it is not a fact that all wealth comprised in estates has been previously taxed. However, looking at the source of wealth for the wealthiest $5 \%$ of Americans, Smith ${ }^{101}$ found that $92.5 \%$ came from earnings, with just $7.5 \%$ from inheritances. Whilst there appears to be no equivalent study in the UK, ${ }^{102}$ an annual survey of the UK's wealthiest people conducted by The Sunday Times showed a noticeable drop in the ranks of those with purely inherited wealth, marking a continued rise in the number of people whose wealth has been accumulated through their ability to make vast amounts of income through playing football, modelling, acting, the music industry and, of course, through large City bonuses and share options, all of which will have been subject to tax when earned. In 2001, one quarter of those on the list inherited their fortunes, the smallest proportion since the list was first compiled in 1989, when about $70 \%$ of the 200 entries recorded enjoyed inherited wealth. ${ }^{103}$ This trend has continued, as evidenced in the most recent survey, ${ }^{104}$ with $77.4 \%$ of the richest 1000 entries being self-made millionaires.

Gale and Slemrod's second argument is that the number of times an item has been taxed is economically meaningless. ${ }^{105}$ These views are also expressed by others, including Murphy and Nagel, who refer to the issue as 'the spurious problems of double taxation'. ${ }^{106}$ More particularly, they argue that taxpayers are frequently taxed twice, for example when they spend after-tax income on goods subject to value added tax (VAT), and that any issue of fairness would have to be about the "cumulative effect of multiple taxes, not about double taxation per se'. ${ }^{107}$ This second argument would

100. W Gale and J Slemrod Rhetoric and Economics in the Estate Tax Debate (final draft, 22 May 2001) Paper Prepared for the National Tax Association Spring Symposium (Washington DC, 7-8 May 2001), available at http://www.brookings.edu/views/papers/gale/20010522.pdf.

101. JP Smith Unequal Wealth and the Incentives to Save (Santa Monica, CA: Rand Corporation, 1995) p 16.

102. Research was undertaken over a number of years in the 1970s, culminating in the observation that ' $[\mathrm{I}] \mathrm{t}$ is difficult to resist the conclusion that inheritance has been the most important single source of wealth inequality in the fairly recent past in twentieth century Britain': C Harbury and D Hitchens Inheritance and Wealth Inequality in Britain (London: George Allen and Unwin, 1979) p 136, but none more recent than this.

103. S Wheelan The Sunday Times 'Rich List' - Britain's Wealthiest 1000 (30 April 2001), available at http://www.wsws.org/articles/2001/apr2001/rich-a30.shtml.

104. 'The Sunday Times Rich List' The Sunday Times 29 April, 2007.

105. Above n 100, pp 23-24.

106. Above n 4, p 144.

107. Ibid. In a similar fashion, Dominic Maxwell, who calls the double taxation argument a 'myth', shares the view that multiple taxation is common, and states that '[T]ransactions, not bank notes, are the proper subject of taxation': Fair Dues: Towards a more Progressive Inheritance Tax (London: Institute for Public Policy Research, 2004) p 11. To suggest that IHT is charged on a 'transaction' is quite simply wrong, since it is imposed on the value of the estate of the deceased immediately before his or her death. It is death that triggers the charge, not the actual transfer of that wealth to another (although the identity of the transferee may become relevant for the purpose of certain exemptions); that is the nature of a mutation duty as opposed to an accessions tax. 
seem to turn on the meaning of 'double taxation'. This term is not defined by Gale and Slemrod, albeit that the foundation for their argument is that taxpayers are 'frequently' taxed twice on the same 'income'. It is suggested that the purchase of goods subject to VAT out of income previously subject to income tax does not amount to double taxation of that income. In this case, although the burden of the tax falls on the purchaser, the VAT is charged on the goods themselves. This is similarly true with the payment of stamp duty land tax on the purchase of real property, where the tax is charged in relation to the price of the property being purchased. By contrast, in the case of IHT, the mere possession of property of a value exceeding the threshold is sufficient to attract the tax: the tax is levied, not on any transaction, but simply on the value of a person's property immediately before his death, property that in many cases, as it has just been shown, has already been subject to income tax or capital gains tax. If double taxation is viewed in this light, why is it any less an issue of fairness than the cumulative effect of a number of taxes? In comparing the estates of A, who spends his income on consumer goods, holidays and the like, and B, who chooses instead to save her income, it can readily be understood that B's estate will bear a heavier burden than will A's; not only has B not had the enjoyment of consumption, but her estate will also bear the burden of IHT on the value of property above the threshold.

Moreover, the fact that wealth may previously have suffered tax may be meaningless to economists, but it is a real issue for taxpayers, and suggests to them that this is far from an equitable tax. It has been said that 'the imposition of extremely unpopular laws upon an unwilling public has no place in a democracy' and that 'the strength of a democracy depends upon there being the freedom and willingness to question the status quo, to constantly seek a better way'. ${ }^{108}$ When, in a demonstration of their democratic rights, taxpayers last took the view that a tax was inequitable and unsustainable, it resulted in massive protest against the community charge (referred to as the poll tax), introduced in $1990 .{ }^{109}$ It is believed that this ultimately led (on 22 November, 1990) to the resignation of Margaret Thatcher (the then Prime Minister) as leader of the Conservative Party, who had given the tax her strong and personal support. All three contenders for her position pledged to abandon the tax and, from the start of 1993-94, John Major, Margaret Thatcher's successor, replaced it with the council tax. This is a lesson that should be borne in mind.

As suggested by the example of A and B, above, the fact of double taxation may have a further impact on taxpayers and could well affect their decision either to save during their lives, or to spend the fruits of their labour and thereby avoid the charge to IHT on death. The importance of this 'spite effect', 110 the need to revenge the government by ensuring that it takes no further tax, should not be overlooked and, indeed, forms the basis of another argument against IHT, namely that the tax may have the effect of reducing savings. This is considered below.

108. DW Haslett 'Is Inheritance Justified?' (1986) 15(2) Philosophy and Public Affairs 122 at 143. By contrast to the present argument, these words were written in the context of abolishing the freedom to leave inheritances. The author was of the view that although, at the time of writing, there was little evidence of public support of such an idea, that public support would eventually come provided that the idea could be justified.

109. The community charge was introduced by the Local Government Finance Act 1988.

110. This phrase, coined by RA Musgrave The Theory of Public Finance (New York: McGrawHill, 1959) is strictly applied to the scenario where individuals may work less as a result of a tax increase to spite the government. 


\section{Increasing house prices}

As far as the impact of increasing house prices on IHT is concerned, using the Gale and Slemrod approach, it should be asked whether this is a fact or simply rhetoric. Recent HMRC statistics show an increase in IHT receipts from $£ 1.6$ billion in 1997/ 98 to $£ 2.4$ billion in $2001 / 02$ to $£ 3.56$ billion in $2006 / 07,{ }^{111}$ and an increase in the number of estates chargeable to tax on death from 18,000 in $1997 / 98$, to 23,000 in $2001 / 02$ to 35,000 in $2006 / 07 .{ }^{112}$ Moreover, $58.5 \%$ of property in estates passing on death in 2003/04 was real property and accounted for 52.5\% of the total capital value. ${ }^{113}$ It has been estimated that the rise in the number of estates comprising private housing to be inherited between 2003 and 2010 is likely to be in the order of 4\%, with an increase in value of that property during the same period of $48 \% .{ }^{114}$ These figures are more than rhetoric and, whilst it cannot be said categorically that the increase in IHT receipts is accounted for entirely by the value of residences, speculation informed by a report of the Public Accounts Committee ${ }^{115}$ suggests that this is the case. It states:

'The number of estates liable to the tax has grown in recent years, reflecting the rising value of assets in estates, particularly of houses and especially of those in London... House prices have grown more quickly than the tax threshold. Around 30,000 estates were liable to IHT in 2003-04, or one in twenty estates, compared with fewer than one in thirty in $1999 .{ }^{116}$ The Revenue estimates that 32,000 estates were liable for the tax in 2004-05, and that 37,000 will be in 2005$06 .{ }^{117}$

It is true to say that the problem could be removed, in part, by simply raising the IHT threshold or, alternatively, by exempting a person's principal private residence from the IHT net. ${ }^{118}$ The Conservative Party consultation document suggested that one of the disadvantages of exempting the principal private residence was that individuals would be encouraged to increase the investment in their homes rather than invest in

111. HMRC statistics (updated to December 2006), Table 1.2, available at http:// www.hmrc.gov.uk/stats/tax_receipts/table1-2.pdf. The figures for 2006/07 are forecasts consistent with those published in the December 2006 Pre-Budget Report, but fall outside the scope of National Statistics.

112. HMRC statistics (updated to December 2006), Table 1.4, available at http://www.hmrc. gov.uk/stats/income_tax/table1-4.pdf.

113. HMRC statistics, Table 12.4, available at http://www.hmrc.gov.uk/stats/inheritance_tax/ 12.4.pdf.

114. The data are from the second Halifax Savings Report HBOS press release, 25 February 2006. According to Halifax figures, the price of homes has risen by an average of $187 \%$ in the last decade; this compares with a rise in shares of $61 \%$ during the same period: Sunday Times 29 October, 2006.

115. Committee of Public Accounts Inheritance Tax Twenty-Ninth Report of Session 200405, HC 174, para 1.2.

116. Comptroller \& Auditor General's Report Inheritance Tax: A Progress Report Session 1998-99, HC 251, para 1.1.

117. 'Executive Summary', Comptroller \& Auditor General's Report, paras 1 and 1.1, Q 96; Inland Revenue Budget 2005, Notice PN2, 16 March 2005.

118. Both of these alternatives were canvassed in Inheritance Tax: A New Direction, above $\mathrm{n}$ 2. It should be noted that the principal private residence is exempt from a charge to capital gains tax: Taxation of Capital Gains Act 1992, s 222. 
other types of assets. ${ }^{119}$ Investment in shares, for example, is plainly a contribution to the common good of the country and should be encouraged. Moreover, it was estimated that this reform 'would come closer to the cost of abolition'. ${ }^{120}$ However, other arguments in favour of abolition of the tax, together with a recognition that it has become impossibly complex, suggest that nothing short of abolition will suffice.

\section{The tax does not fall on the very wealthy}

Careful estate planning through the sensible use of the nil rate band (which applies up to the threshold of $£ 300,000)^{121}$ and of the exemptions described earlier in this paper can virtually eliminate the tax. Thus, for example, in addition to the yearly gift exemption of $£ 3000$, individuals can give away up to $£ 300,000$ every 7 years free of IHT and make exempt transfers to their spouses or civil partners. Beyond that, there also exist a number of increasingly complex methods for reducing the burden of IHT. ${ }^{122}$ For a number of reasons, it is clear that those with the largest estates have the greatest ability to engage in estate planning. First, those who are very wealthy are in a position to give away large amounts of their wealth, whilst still retaining sufficient for their needs during the rest of their lives. ${ }^{123}$ Secondly, a number of estate planning schemes are costly and may take a long time to implement. Finally, families with long histories of wealth are more likely to be familiar with such planning schemes. Thus it is that a disproportionate burden of IHT falls on those with modest wealth.

\section{EQUITY CRITERIA}

It has been said that 'there is a general consensus that gifts and bequests are a proper subject for tax', ${ }^{124}$ but why? Recent reports have proposed either a completely new system of taxing the transfer of wealth on death ${ }^{125}$ or substantial reform of the current regime ${ }^{126}$ but, before either of these can be attempted, the objective for levying a charge on death must be established. There appear to be three possible reasons for imposing a charge on a person's assets at the point of death.

\section{Redistribution}

For many, the most compelling reason for an estate tax is that the tax system should be fair. Fairness has traditionally been seen as 'a standard for evaluating differences

119. Ibid, at p.8.

120. Ibid.

121. The nil rate band; see above $\mathrm{n} 5$.

122. For example, life insurance trusts and offshore trusts.

123. See above nn 72-74. The exemption that permits 'normal expenditure out of income' (IHTA 1984, s 21) is especially favourble to those with large amounts of wealth.

124. The Structure and Reform of Direct Taxation, Report of a Committee chaired by Professor JE Meade (London: The Institute for Fiscal Studies, 1978) p 41.

125. The Commission on Taxation and Citizenship Paying for Progress: A New Politics of Tax for Public Spending (London: Fabian Society, 2000); R Patrick and M Jacobs Wealth's Fair Measure: The Reform of Inheritance Tax (London: Fabian Society, 2003).

126. D Maxwell Fair Dues: Towards a more Progressive Inheritance Tax (London: Institute for Public Policy Research, 2004). 
in the tax treatment of different people: the principle that like-situated persons must be burdened equally and relevantly unlike persons unequally'. ${ }^{127}$ This statement refers to horizontal and vertical equity respectively, but it is vertical equity that is critical to the current debate since, theoretically, once a rate has been set for somebody with greater income or wealth than another, that same rate should then be set for another person who has the same income or wealth. Vertical equity is achieved by taxing people according to their ability to pay which, since the basis of our tax system is income, is manifested through the imposition of progressive rates as a taxpayer's income increases. ${ }^{128}$ It is believed, however, that income alone is not a true measure of a person's ability to pay, and that ownership of wealth must also play a vital part either through an annual wealth tax ${ }^{129}$ or a wealth transfer tax, ${ }^{130}$ or both. There would appear to be two possible reasons for this. Some would argue that the mere fact of holding wealth is sufficient to attract tax, since with it brings 'opportunity, security, social power, influence and independence', not to mention 'a source of income which is compatible with a life of leisure'. ${ }^{131}$ This is, in part, discussed in the section below, but for now it has to be said that to impose a tax for this reason alone without a concomitant commitment to improve the living standards of the poorest in society looks confiscatory ${ }^{132}$ and, it is suggested, would be politically impossible to achieve in the UK. The annual wealth tax that was proposed by the former Chancellor of the Exchequer, Denis Healey, ${ }^{133}$ failed to reach the statute book, in part because there was a division in the then Labour Party between those who saw the tax as a means of 'penalising' the rich, with little concern as to whether it would have any effect on those at the other end of the wealth scale, and those who viewed the tax as an instrument of redistribution. Thus, as Cedric Sandford has written:

'An AWT (annual wealth tax) is one method of taxing the wealthy more heavily, whether to put some constraint on the growth of inequality in income and wealth, or positively to reduce inequality. In the more limited case, an AWT can be thought of as a substitute for the top rates of a progressive income tax ... If the radical objective of positively reducing inequalities is sought, then the rates of AWT can

127. Murphy and Nagel, above $\mathrm{n} 4, \mathrm{p} 12$.

128. Whether income tax rates in the UK are truly progressive any longer is, however, questionable, given a single higher rate band of $40 \%$, which starts with taxable income of only $£ 39,825$ (for the tax year 2007/08).

129. For reasons explained below, a proposed wealth tax never came to fruition in the UK. Such a tax has also been rejected by.

130. Such as estate duty, capital transfer tax and inheritance tax.

131. The Structure and Reform of Direct Taxation, above $\mathrm{n} 124, \mathrm{p} 40$. See also pp 317-318.

132. This raises the issue of whether the imposition of a tax on this basis might be in breach of Art 1 of Protocol 1 (peaceful possession of property) of the European Convention for the Protection of Human Rights and Fundamental Freedoms 1950. Given the caveat to that Convention right expressly reserves to Member States the right to raise taxes, it is thought that this is unlikely. Moreover, this author has previously expressed the view that taxpayers are unlikely to be successful in challenging government tax policy generally (as opposed to administrative actions of HMRC), since courts allow governments a very wide margin of appreciation; see $\mathrm{N}$ Lee 'The effect of the Human Rights Act on taxation policy and administration' (2004) 2(2) Journal of Tax Research 155. Note also the view of Robert Nozick in Anarchy, State and Utopia (Oxford: Basil Blackwell, 1974) that, in effect, all taxation is confiscatory and prevents individuals from disposing of their property as they would wish; see, in particular, pp 167-172. 133. See the Green Paper Wealth Tax Cmnd. 5704, 1974. 
be set at a level such that, when taken in conjunction with income tax, after allowing for reasonable consumption expenditure, the rich have to dispose of assets in order to pay both income tax and AWT.' 134

Others are of the view that part of a person's wealth should be available for redistribution in order to promote a more equal distribution of the ownership of wealth. This, of course, begs the question of what is meant by equality. If it refers to equality of opportunity, in the sense that everyone should start out in life equally, then this comes dangerously close to advocating the abolition of inheritances and, despite the fact that it has been argued that such a policy could co-exist with capitalism, ${ }^{135}$ it is submitted that it would not generally be tolerated by the citizens of a country with a dominant home-owning ethos. If, instead, equality refers to outcome, it is suggestive of redistribution in a welfare sense, that is, in improving the conditions of poorer members in society, and it is for this which those who continue to advocate estate taxation generally argue.

However, none of the estate taxes that have been implemented in the UK appears to have brought about a change in wealth ownership, as the table below demonstrates. ${ }^{136}$

This table shows not only that estate taxation has been unsuccessful in redistributing wealth, with half the population owning only $7 \%$ of total wealth, $1 \%$ less than in 1976, but also that an increasing number of people have become wealthier through home ownership.

Given that IHT forms part of the general revenues collected by government, which, in addition to paying for public services, are redistributed as income in some form of income support, it is not really surprising that wealth ownership has remained fairly constant for 30 years. ${ }^{137}$ Redistribution of income in the form of means-tested benefits is generally at subsistence level and does not allow for accumulation of that income so as to form a wealth base. It is true that the new child trust funds ${ }^{138}$ were introduced with the specific intention of conferring a measure of wealth on those who would otherwise have nothing, and could thus be seen as the one true example of wealth redistribution. However, the amounts concerned are relatively small ${ }^{139}$ and the system

134. C Sandford More Key Issues in Tax Reform (Bath: Fiscal Publications, 1995) p 51.

135. DW Haslett 'Is inheritance justified' (1986) 15(2) Philosophy and Public Affairs 122.

136. HM Revenue \& Customs National Statistics (8 May 2006), available at http://www. statistics.gov.uk/cci/nugget.asp?id=2; 1976 represents the year after estate duty was replaced by CTT; 1986 was the year in which IHT replaced CTT.

137. According to an analysis of recent figures (Department of Work and Pensions Households Below Average Income 1994/95-2005/06 (Leeds: Corporate Document Services, 2007), the number of people living in relative poverty (that is, living in households with less than $60 \%$ of the median income) actually rose between 2004/05 and 2005/06 from 12.1 million to 12.7 million (measuring incomes after housing costs) and from 10.0 million to 10.4 million (measuring incomes before housing costs): $\mathrm{M}$ Brewer et al Poverty and Inequality in the UK: 2007 Institute for Fiscal Studies, Presentation on 28 March, 2007.

138. See the Child Trust Funds Act 2004.

139. All children in the UK born after 31 August 2002 will have a child trust fund account, and will receive an initial payment of $£ 250$, with children being looked after by local authorities receiving a higher rate. Children from low-income families will receive a further payment of $£ 250$. It may be that, in the future, further payments into these funds will be made by the government, eg on a child's seventh birthday; consultation on this continues. 
Table 1: Wealth ownership in the UK 1976-2003

\begin{tabular}{ccccc}
\hline Year & $\begin{array}{c}\text { Wealth owned by } \\
\text { most wealthy 1\% } \\
\text { including value } \\
\text { of dwellings }\end{array}$ & $\begin{array}{c}\text { Wealth owned by } \\
\text { most wealthy 1\% } \\
\text { excluding value } \\
\text { of dwellings }\end{array}$ & $\begin{array}{c}\text { Wealth owned by } \\
\text { most wealthy 50\% } \\
\text { including value } \\
\text { of dwellings }\end{array}$ & $\begin{array}{c}\text { Wealth owned by } \\
\text { most wealthy 50\% } \\
\text { excluding value } \\
\text { of dwellings }\end{array}$ \\
\hline 1976 & 21 & 23 & 92 & 88 \\
1986 & 18 & 25 & 90 & 89 \\
1996 & 20 & 26 & 93 & 94 \\
2003 & 21 & 34 & 93 & 99 \\
\hline
\end{tabular}

could possibly exacerbate the problem of wealth inequality. ${ }^{140}$ The only real way of securing an equal outcome as far as wealth is concerned is to impose virtually a $100 \%$ tax on estates so that, irrespective of what the revenue collected is used for, there is more equality because those who were wealthy are no longer so. But this is not truly redistribution of wealth; rather, it resembles a policy of seeking to achieve equality of opportunity, and it has already been suggested that no political party would dare to suggest such a policy if it wished to be elected or re-elected.

Moreover, as far as redistribution of wealth in the form of income is concerned generally, whilst most people are likely to be in favour of a measure of redistribution in the form of, say, tax credits, this can bring with it the claim that some can opt out of work, knowing that they will be supported by the state through the taxation of others. This claim has been substantiated by a recent study concerning the conflict between redistributing income and strengthening financial work incentives, where it was concluded that tax and benefit changes made since 1999 (and thus embracing tax credits) have had the effect of weakening financial work incentives. ${ }^{141}$ The equity in this situation seems questionable.

Furthermore, when table 1 above is viewed in light of both the figures that show an increase in the IHT yield, and the knowledge that the very wealthy are able to avoid the charge through making lifetime gifts and surviving 7 years, the tax that is imposed in the interests of fairness looks anything but fair, with people of moderate wealth feeling the burden of a tax that is not improving the situation of those with little or no wealth.

140. Since all children are entitled to a child trust fund account, to which parents can contribute, it follows that the children of those with existing means who can afford to make the extra contributions will enjoy a very much larger asset on maturity; see N Wikeley 'Child trust funds - asset-based welfare or a recipe for increased inequality?' (2004) 11 Journal of Social Security Law 189.

141. S Adam. M Brewer and A Shephard The Poverty Trade-Off: Work Incentives and Income Redistribution in Britain (London: Institute for Fiscal Studies, October 2006). It is this author's view that the working families' tax credit was specifically designed to strengthen work incentives, being payable only if at least one of a couple was working. The separation of this credit into the working tax credit and the child tax credit, with child tax credit being payable irrespective of whether a member of the family was in work, was bound to have the reverse effect. 


\section{Impeding the accumulation of wealth}

The second reason for an estate tax, perhaps together with a gift tax, is to impede the accumulation of vast fortunes, since it is believed that the owners of such fortunes may wield too much political influence, contrary to democratic principles. Indeed, in arguing for the actual abolition of inheritance, Haslett wrote that 'all great concentrations of economic power are suspicious, whether emanating from government, corporations, or individuals' ${ }^{142}$ However, since this has less to do with any issue of welfare or of benefit to others, and rather more with the democratic process, it is suggested that this is not a good justification for taxing wealth. This view is shared by Murphy and Nagel, who are of the further opinion that the problem should be resolved instead by controlling the way in which political parties raise funds. ${ }^{143}$

\section{Raising revenue}

One final reason for levying a tax on the value of estates on death is that it is an easy way of raising extra revenue. Despite the view that such a tax 'cannot be expected to perform a significant revenue-raising role', ${ }^{144}$ there is no doubt that it is currently helping to fill the public coffers (as witnessed by the way in which the yield has increased over recent years). But can yield, without more, really ever be used as a justification for such a tax? Whilst it would be easy to suggest that a tax is only ever justified on the grounds of yield, factually this is simply not the case. CGT was introduced in 1965 in order 'to provide a background of equity and fair play" ${ }^{145}$ and, as Whiting has commented, it was not 'expected to generate significant revenue. [Its] function was to be radical, and to restore legitimacy to the tax system by making it fairer'. ${ }^{146}$ Accordingly, one line of thought suggests that yield can only ever be incidental to the more fundamental purpose of justice and equity for imposing the tax. Indeed, it was said in 1945 that 'death duties in this generation are an instrument of social, not fiscal, legislation', ${ }^{147}$ and, further, that:

'because of the small contribution which death duties in Britain now make to the revenue ... revenue considerations are comparatively unimportant and a main

142. Haslett, above $\mathrm{n} 135$, at 135 . See also D Duff 'Taxing inherited wealth: a philosophical argument' (1993) VI:1 Canadian Journal of Law and Jurisprudence 4 at 24-25.

143. Above $\mathrm{n} 4, \mathrm{p} 115$. The need for this type of control has clearly been demonstrated by events in 2006, which have brought to light the fact that political parties had found the means to circumvent the necessity of declaring donations made to them. See the Report of the Constitutional Affairs Select Committee: House of Commons Constitutional Affairs Committee Party Funding First Report of Session 2006-07, HC 163, 19 December 2006 and H Phillips Strengthening Democracy: Fair and Sustainable Funding of Political Parties, The Review of the Funding of Political Parties (15 March 2007), available at http://www.partyfundingreview. gov.uk/files/strengthening_democracy.pdf. See also O Gay, I White and R Kelly The Funding of Political Parties House of Commons Research Library Research Paper 07/34 (Parliament and Constitution Centre, 10 April 2007).

144. Duff, above $n 142$, at $7-8$.

145. Budget Speech, The Chancellor of the Exchequer, James Callaghan Hansard HC Deb, vol 710, col 245, 6 April 1965.

146. RC Whiting 'Ideology and reform in Labour's tax strategy, 1964-1970' (1998) 41(4) The Historical Journal 1121 at 1122.

147. Professor H J Rudick 'A proposal for an accessions tax’ (1945) 1 Tax Law Review 29. 
criterion for determining the best form of death duty ought to be its effect in reducing concentrations of wealth and spreading it more evenly. ${ }^{, 148}$

Another view is that it is a matter of politics, a weighing of the cost of continuing with the tax in the face of opposition to it against the revenues raised by it. ${ }^{149}$ It has previously been mentioned that, in Victorian times, it was perceived that an estate tax would be more acceptable to people than an increase in income tax, but times have changed. Although the yield from IHT has increased over recent years, it is still only a fraction of what it was in Victorian times and, moreover, it has become a very unpopular tax indeed, mainly because it is now being imposed upon a larger proportion of the population than ever before and, it is suggested, than ever was countenanced on its introduction. ${ }^{150}$ Accordingly, in the absence of any primary justification for the continuation of IHT, it is possible that, politically, a government may be forced to abandon the tax, particularly if there can be shown to exist alternative means of raising the same amount of revenues. This is considered below.

\section{ECONOMIC EFFICIENCY ${ }^{151}$}

The main economic argument in favour of retaining IHT is, of course, that its yield of $£ 3.56$ billion $^{152}$ would be hard to replace if it were to be abolished, albeit that it continues to represent only a small proportion of total tax revenues. It is interesting at this juncture to make some historical comparisons. Death duties were first introduced in order to raise money; it was believed that this was a more palatable way of raising revenue than through the income tax. The introduction of estate duty in 1894, with its graduated rates, was an attempt to raise revenue in an equitable manner. Over more recent years, estate duty and its successors CTT and IHT yielded only a tiny proportion of total tax revenues, at which time it was said that the tax had to be retained on grounds of equity. It has already been demonstrated that these equity arguments are no longer particularly strong; clearly the tax is being retained and, indeed, significantly strengthened, ${ }^{153}$ for the purposes of yield, which has increased over the immediate past, largely due to the rising value of residential property. It is submitted that, in the absence of strong equitable reasons, IHT should not be retained for its yield alone. But what of the lost $£ 3.56$ billion that would arise on its abolition? It should first be stressed that this sum represents a mere $0.84 \%$ of total tax

148. Sanford, Willis and Ironside, above n 34, p 10, para 1.24.

149. Duff, above $\mathrm{n} 142$, at 8 .

150. The hostility towards IHT was revealed in a piece of public opinion research on IHT carried out by the Institute for Public Policy Research and Oxford University, referred to in Maxwell, above n 107, p 13.

151. For an economist's view, see B Bracewell-Milnes Will to Succeed: Inheritance without Taxation (London Adam Smith Institute, 1994); Euthanasia for Death Duties, above n 13; N Kaldor 'The income burden of capital taxes' (1942) Summer Review of Economic Studies; reprinted in the American Economic Association's Readings in the Economics of Taxation (Homewood IL: Richard D Irwin, 1949); G Erreygers 'Views on inheritance in the history of economic thought' in G Erreygers and T Vandevelde (eds) Is Inheritance Legitimate? Ethical and Economic Aspects of Wealth Transfers (Berlin: Springer-Verlag, 1997).

152. HMRC Annual Receipts T1.2 (updated to December 2006).

153. See the changes introduced by the Finance Act 2006. 
revenues, ${ }^{154}$ and thus the yield argument may be an overstated one. Moreover, it has been argued that although as a 'first round effect' IHT raises this amount of revenue, if IHT was not imposed, the money representing the tax might remain invested or be spent and, in either case, as a 'second round effect', it would bear income tax, excise duties or VAT and maybe more. ${ }^{155}$ Accordingly, abolition of IHT and the loss of revenues therefrom would be mitigated by an increase in tax revenues elsewhere. Moreover, it is quite possible that any abolition of IHT could be accompanied by the re-imposition of capital gains tax (CGT) on death, ${ }^{156}$ a measure considered by the recent report of the Conservative Party's Tax Commission ${ }^{157}$ and believed to be much fairer in that what is being taxed is an increase in the value of assets, something that has not previously been taxed. In addition, further revenue could be raised by the imposition of alternative taxes. ${ }^{158}$

Having disposed of the main economic argument for the retention of IHT, below are just a few of the more common economic arguments that are raised in favour of the abolition of IHT, some of which, in this author's view, may have merit.

\section{High cost of administration and compliance}

It is claimed that IHT is high in both administrative and compliance costs. ${ }^{159}$ The administrative costs of the various taxes are shown in the table overleaf. ${ }^{160}$

What is clear from this table is that IHT is one of the more costly taxes to collect, particularly when viewed alongside other direct taxes such as corporation tax and CGT. However, administrative costs alone do not represent the whole picture. Given the complexity of the IHT legislation, increased still further by the changes introduced by the Finance Act 2006, compliance costs are also bound to be high. Moreover, as Bracewell-Milnes explains, a further major compliance cost to the taxpayer (in the guise of the executor) is the requirement to value assets that change hands otherwise than by sale, and many estates that may not be subject to IHT are still obliged to

154. This percentage is based on the information in HMRC Annual Receipts, above n 152. Total tax revenues include the revenue from all the taxes administered by HMRC (which body represents the former Inland Revenue and Her Majesty's Customs and Excise).

155. Bracewell-Milnes Euthanasia for Death Duties, above n 13, pp 28-29.

156. This is discussed below.

157. See above $\mathrm{n} 2$. The Tax Commission's proposals exempt any gain arising in respect of the value of the main private residence from CGT on death, in the same way that it is currently exempt on inter vivos disposals. This is an issue that needs further consideration, but is outside the scope of this paper.

158. For example, see the recent Liberal Democrat proposals to replace Air Passenger Duty with an aircraft tax, dependent upon the number of flights rather than the number of passengers, an increase in Vehicle Excise Duty for cars that cause the most pollution and an increase in fuel duty in line with inflation: Liberal Democrats Tax Commission Fairer, Simpler, Greener: Policy Paper No 75 (August 2006). Given that such taxes are meant to be helping the environment, it is thought that they would be tolerated by taxpayers.

159. Compliance costs are the costs incurred by taxpayers in ordering their affairs to take account of IHT, and by personal representatives in the course of administering taxpayers' estates.

160. The table is extracted from HMRC Annual Report 2005/06 and Autumn Performance Report 2006 Cm 6983, December 2006. 
Table 2: Cost of collection of various taxes (pence per $£$ collected) for 2005/06

\begin{tabular}{lc}
\hline Income Tax & 1.27 \\
Corporation Tax & 0.71 \\
Petroleum Revenue Tax & 0.13 \\
Capital Gains Tax & 0.92 \\
Inheritance Tax & 1.01 \\
Stamp Taxes & 0.20 \\
National Insurance Contributions & 0.42 \\
VAT & 0.55 \\
Insurance Premium Tax & 0.14 \\
Hydrocarbon Oils & 0.16 \\
Alcohol & 0.54 \\
Tobacco & 1.83 \\
Gambling Taxes & 0.29 \\
Environmental Taxes & 0.26 \\
Air Passenger Duty & 0.05 \\
International Trade & 6.07 \\
Overall cost (pence per $£$ collected) & 1.11 \\
\hline
\end{tabular}

spend time and money on valuations in order to establish that they are not liable. ${ }^{161}$ However, the high cost argument alone does not give sufficient cause to claim for abolition. As seen from the above table, CGT is also relatively costly to collect; CGT was introduced in 1965 as a separate tax purely for reasons of equity, ${ }^{162}$ and whilst taxpayers would prefer not to pay tax on their capital gains, generally they understand the arguments for doing so. Moreover, with the introduction of taper relief, which reduces the gain depending on the length of ownership of the capital asset being disposed of, capital gains tax is perceived as a reasonably fair tax. An attempt has already been made to show that IHT is not a fair tax, and plays little or no part in the redistribution of wealth. The conclusion must be that that there exists nothing to justify the high costs of administering and complying with IHT.

\section{IHT imposes economic burdens}

Economists would argue that the burden of a tax is not simply represented by the amount of tax that actually has to be paid; in addition to the administrative and compliance costs (considered above), account also has to be taken of the added 'costs' of the imposition of, or increase in, a tax, referred to as the 'excess burden'. To use

161. Bracewell-Milnes Euthanasia for Death Duties, above n 13, p 28. This point was highlighted by Lord Sheikh in the recent House of Lords debate on IHT; see Hansard HL Deb, vol 689, col 457, 1 February, 2007.

162. See above nn 145 and 146. Put simply, capital gains tax is charged on the gain arising from the disposal of a capital asset. 
a very simple example, if an additional tax was placed on wholemeal bread, forcing taxpayers who would not do so otherwise to buy white bread, then that change in behaviour is an additional economic burden resulting from the imposition of the tax. IHT has a similar impact insofar as it may induce people to change their behaviour in order to reduce their tax liability. Thus, the concern has been expressed that the elderly may make gifts too early and not in their own best interests; ${ }^{163}$ grandparents may have preferred to wait to give part of their wealth to their children but, because of the tax, they decide to do so immediately, normally through an A\&M trust. ${ }^{164}$ Moreover, the effect of making premature gifts can also weaken businesses. Although relief protects both business and agricultural assets from liability to IHT, some taxpayers give them away early for fear that such relief may be removed; the recipients of the assets will probably receive them far too early for their own good, and may squander their value and destroy the businesses. ${ }^{165}$ By the same token, it is also possible to argue that people make large charitable donations in order to minimise IHT, thereby imposing an excess burden. These examples illustrate ways in which the tax has imposed an excess burden insofar as it has caused people to act in a way in which they would not otherwise have done. What is difficult in any of these cases is to establish whether, as a matter of fact, these people really would have acted differently, and thus whether IHT does impose additional economic burdens. Moreover, as far as charitable bequests are concerned, if this could be proved, then it might provide an argument for retaining IHT on the basis that its abolition would result in less charitable giving. In truth, it is surely fanciful to suggest that, for example, Bill Gates would have been less likely to create his charitable educational foundation in the absence of estate taxes. ${ }^{166}$ Accordingly, on the basis of those particular cases, all that can be said is that it is possible that IHT may impose an excess burden, but that, standing alone, it may not be a strong enough argument to justify abolition of the tax. However, worthy of consideration is the fact that not only will the estate of a person who chose to save her income, rather then to spend it, be liable to IHT (provided it is above the threshold), or a greater amount of IHT, in comparison to the estate of a person who did not accumulate his income and spent it instead, but also that person will also have foregone the actual pleasure of spending. This too could be perceived as an excess burden.

A more general concern about the economic burden of IHT is that, unlike an accessions tax, it is related to the size of the estate rather than to the size of inheritance received by each beneficiary. The result of our misnamed system is that, in a large number of cases, more IHT is payable than would have been the case had the tax fallen on the recipient. This argument is hard to refute. However, as discussed earlier, a move to an accessions tax would result in even higher administrative and compliance costs than we currently experience. These two factors together go a long way towards supporting the abolition of death duties generally.

163. Hansard HL Deb, vol 689, col 451, 1 February, 2007.

164. Because of the changes introduced by the Finance Act 2006, this mechanism will no longer be effective for IHT reliefs.

165. See above n 163 .

166. Interestingly, William Gates Senior has campaigned against the abolition of the estate tax in the USA. See, eg, Forum on Estate Tax, Tax Policy Centre, with William Gates Senior as the featured speaker, available at http://www.taxpolicycentre.org/publications/template.cfm? PubID $=900584$. 


\section{IHT reduces savings}

Whether the imposition of IHT leads to a reduction in savings is, according to Gale and Slemrod, ${ }^{167}$ ambiguous. They state that much of what is said about this issue is rhetoric, and there are few facts to be found. Those who have argued in favour of abolishing inheritances (in effect, imposing a 100\% charge on inheritances) have found the savings argument to be the most difficult to counter. Theory would have it that abolishing inheritance would 'shift people's consumption - savings pattern more in the direction of consumption'. ${ }^{168}$ However, this argument can be overstated, particularly bearing in mind that people need and want to save for their retirement. Moreover:

'Investments would still remain attractive aside from the savings motive; they combine the excitement of a gamble with the satisfaction of doing what is socially useful. And many people, especially the more wealthy, would still want to save for charitable purposes; to have a scholarship or perhaps a university building named after them, to support medical research, or even to establish a charitable foundation to carry on with some project in which they deeply believe.' 169

If this is true in the case of abolition of inheritance, it must also be true where IHT is imposed at a rate far below $100 \%$. Further, it should be noted that corporate investment (for example in the guise of research and development or expenditure on plant and machinery) is unaffected by IHT. In light of this, the author is of the view that it is unlikely that IHT markedly affects savings as far as wealth owners are concerned, although potential recipients of inheritances may well decide to spend rather than save in the knowledge that there will be money coming to them in the future.

\section{FUNDING THE ABOLITION OF IHT: THE REINTRODUCTION OF A CGT CHARGE ON DEATH}

As already explained, CGT is charged on the gain, if any, arising from a disposal of an asset by way of gift, exchange or sale. Until 1971, the charge also operated on death, when there was deemed to have been a disposal by the deceased to the personal representatives. Since that time, death has not been a disposal for CGT purposes, ${ }^{170}$ although the personal representatives are deemed to acquire the estate assets for a consideration equal to market value. This means that any gain accruing between the time of the testator's acquisition of the assets and his or her death will currently escape a charge to CGT. The rationale for this was to avoid a double charge to the relevant estate tax and CGT.

Currently, CGT is charged at a taxpayer's marginal rate of income tax $;{ }^{171}$ accordingly, those taxpayers paying higher rate income tax at $40 \%$ will also be subject to CGT at the same rate. Disposals between spouses and civil partners are deemed to

167. Gale and Slemrod, above $\mathrm{n} 100$.

168. Haslett, above n 108, at 146.

169. Ibid, at 147.

170. Taxation of Capital Gains Act 1992, s 62.

171. Ibid, $s 4$. 
be for such value that gives rise to neither a loss nor a gain, ${ }^{172}$ with the result that although there will be no CGT charge on inter-spouse transfers, the gain that has accrued on the relevant asset during their ownership will be captured on a disposal to a third party.

There are some generous reliefs available, the most important for the purpose of this paper being the principal private residence exemption, ${ }^{173}$ which, as its name suggests, exempts a charge on a gain made on the disposal of a taxpayer's main residence, provided that it had not been acquired 'wholly or partly for the purpose of realising a gain from the disposal of it' ${ }^{174}$

Importantly, taper relief was introduced in $1998,{ }^{175}$ with the aim of encouraging long-term investment. Its purpose is similar to that of indexation in that the amount of CGT paid is reduced to take account of inflation, and it operates by reducing by a percentage the amount of the gain for every year an asset has been held. Since the relief was introduced, it has been extended substantially so that, in respect of business assets held for a mere 2 years, the effective rate of CGT is $10 \% .{ }^{176}$

Since CGT is a charge on the gain arising from the disposal, or deemed disposal, of an asset, it must be favoured over IHT because it is charging a new source of revenue, and the argument about double taxation does not, therefore, arise. In terms of administrative costs, it has already been seen that CGT is cheaper to collect than IHT; in any event, for current CGT purposes, assets have to be valued at the time of death in order that the 'uplift' provision referred to above may operate.

It is suggested that the equity of a CGT charge on death would depend, amongst other things, upon the available exemptions and the operation of taper relief. Issues that would have to be considered would include whether to maintain the exemption for the main residence, ensuring also that administrative and compliance costs are kept to a minimum, ${ }^{177}$ or withdraw it on the occasion of death, but perhaps simultaneously amend taper relief so that its operation with respect to the main residence operated more generously. It would also have to be decided whether there should be an exempt amount of CGT on death, and whether this should be set at a higher rate than the current annual exemption of $£ 9200$ (for 2007/08).

Reintroduction of CGT on death would be just one of a number of measures that could be taken to replace revenue lost from the abolition of IHT. Environmental taxes could prove another source, although pressure may be brought to hypothecate such taxes in the future. Further, and as previously mentioned, the IHT that would have been chargeable will either be spent, in which case, further VAT may possibly be raised, or it will be invested, in which case income tax will be charged on any income arising, along with CGT on any gain made on a disposal of the investment. ${ }^{178}$

172. Ibid, s 58 as amended.

173. Ibid, s 222.

174. Ibid, s 224(3).

175. FA 1998, s 121; see Taxation of Chargeable Gains Act 1992, s 2A.

176. FA 2002, s 46; see Taxation of Chargeable Gains Act 1992, s 2 A(5).

177. It has already been established that, for a large number of those with only moderate wealth, most of that wealth comprises the family home. If this were to be exempt, there would be no need for a valuation of it by the executors, thus reducing administrative and compliance costs.

178. Although it should be noted that there are limited ways (through Independent Savings Accounts (ISAs)) for investments to be made, allowing for both income and CGT relief. 


\section{AUSTRALIA, CANADA AND SWEDEN}

Since all three of these jurisdictions have abolished their estates and gifts taxes, ${ }^{179}$ it may be instructive to consider the reasons for such abolition, and to discover whether any parallels can be drawn with the UK. ${ }^{180}$ Although it must be recognised that Sweden's social structure is very different to that of the UK, and that income and wealth is more evenly distributed, a comparison with Sweden may yet be of greater significance since both Australia and Canada are federations, and at least one of the reasons for the abolition of the estates and gifts taxes in those jurisdictions may not be of relevance to a non-federal jurisdiction.

Canada abolished its federal gift and estate taxes with effect from 1 January 1972; provincial gift and estate taxes were abolished between 1971 and 1985. Australia dispensed with its state and federal death and gift duties between 1 January 1977 and 31 December 1981. The reasons for the abolition of these taxes in both counties are set out clearly by Duff. ${ }^{181}$ Abolition in Canada stemmed from the Report of the Carter Commission, ${ }^{182}$ which proposed a comprehensive tax base, catching all gains made

179. New Zealand abolished its estates tax in 1999, but the gifts tax remains in place. It is for this reason, together with the fact that it has been said that part of the reason for the abolition of the estates tax was the fact of abolition of the estates tax in Australia and because of the free movement of nationals between New Zealand and Australia (C Sandford Why Tax Systems Differ:A Comparative Study of the Political Economy of Taxation (Bath: Fiscal Publications, 2000) p 100) that New Zealand is not specifically considered in this paper. Other countries to have abolished their estate taxes include Russia, Hong Kong and Italy, although the succession tax is to be reintroduced in Italy amidst criticism that the rules are being introduced by government rather than by Parliament and that they are poorly drafted; see Guardian Abroad 25 October 2006, available at http://www.guardianabroad.co.uk/finance-tax/article/144.

180. This article has not attempted to draw any comparison between the income tax rates of these countries because, as will be seen, the arguments for abolition were without reference to income tax. Of greater and more direct interest is the existence of an annual wealth tax, or a CGT charge on death. Indeed, in a recent House of Lords debate on IHT, Lord Burnett said, 'Although I shall be adverting principally to that tax [inheritance tax], your Lordships will understand that our discussions would be incomplete if we did not also discuss the interrelationship of that tax with capital gains tax' (Hansard HL Deb, vol 689, col 451, 1 February 2007). Both an annual wealth tax and CGT are referred to below. Moreover, whilst it is too early to evaluate the impact that the abolition of IGT has made in Sweden, it is interesting to note the lack of literature on the subject in Australia and Canada, suggesting that both countries have accepted, or are at least resigned to, abolition. Duff (see below n 181) believes that an estates tax should exist for redistributive purposes, but that politically it is unlikely to be reintroduced. The issue might be reawakened in Canada in light of the debate currently taking place in the USA over whether to abolish the federal estate tax. As Auerbach has pointed out, 'The US has been struggling since 2001 with the question of whether to repeal its estates tax (current law would repeal it for one year, in 2010, before reinstating it)': A Auerbach The Future of Capital Income Tax paper given for the annual lecture of the Institute for Fiscal Studies (4 September 2006). According to an editorial in the Wall Street Journal (8 July 2005), with a combined federal/state estate tax rate of above $50 \%$ on the estates of the wealthiest, the 'U.S. now has the distinction of imposing the most onerous death tax in the industrialized world'.

181. D Duff 'The abolition of wealth transfer taxes: lessons from Canada, Australia, and New Zealand' (2005) 3 Pittsburgh Tax Review 72. A shorter version of this paper, dealing with Canada only, can be found in J Tiley (ed) Studies in the History of Tax Law (No 2) (Cambridge: Cambridge University Press, 2006) pp 309-334.

182. The Royal Commission on Taxation (Ottawa, Queen's Printer, 1966). 
by a taxpayer in a year, both income and capital gains (including those arising when property is transferred by way of gift and on death) ${ }^{183}$ as well as gifts and inheritances. ${ }^{184}$

Because gifts and inheritances were to be treated as the income of a recipient in the year of receipt, the Commission proposed the abolition of the existing wealth transfer taxes. Although the proposals were eventually rejected, a newly elected government amended the existing federal estate and gift taxes by integrating them into a cumulative progressive tax, imposing higher rates on estates of less than $\$ 5$ million. Despite the fact that there was introduced for the first time an exemption for transfers between spouses, small businesses and the farming communities were bitterly opposed to the fundamental changes. The strength of their opposition, which extended to the proposals, later enacted, that sought additionally to tax accrued capital gains on death, finally led to the abolition of the federal estate and gift taxes. In order to prevent Alberta, which had refused to enact a provincial succession duty and gift tax, from becoming a tax haven, other provinces gradually abandoned their own succession duty and gift taxes.

It has been said that 'Australia today remains one of the only developed nations without some form of explicit or de facto IHT' ${ }^{185}$ Not only are there no estate or gifts taxes, but CGT is not charged on death either. Abolition of gift and death duties began in 1978 in Queensland, described as 'a hotbed of agrarian resentment against death duties'. ${ }^{186}$ Malcolm Fraser, then federal Prime Minister, endorsed this action and abolished federal IHT in the same year. With the same fears that had forced the Canadian provinces to abandon their estate and gifts taxes, the Australian states gradually followed Queensland's example.

In the case of both Canada and Australia, Duff is of the view that abolition of death duties and gift taxes can be explained by the application of 'public choice theories of politically efficient revenue structures'. ${ }^{187}$ In simple terms, governments will weigh the political costs, that is, the possible loss of electoral support, in choosing, for example, whether to introduce a new tax rather than increasing an existing one, or to repeal an old tax which, compared to other taxes, has become unpopular or, indeed, to reduce public spending rather than increase, or introduce a new, tax. In Canada, a combination of the dislike expressed by a powerful group of taxpayers towards the Carter Commission Report, the merging of the estate and gifts taxes, the imposition of higher rates and the proposal to tax gains at death made the estate and gift tax politically costly. The result was that, if it wanted to retain support, the government of the day could not afford not to abolish it. As far as Australia is concerned, Duff gives three factors which increased the political costs of death and gifts duties, leading to their eventual abolition. First, exemptions failed to keep pace with inflation, leading to relatively modest estates being taxed; secondly, there was a failure to integrate state and federal duties; and, thirdly, the taxes could easily be avoided. ${ }^{188}$

183. Ibid, paras 368-380.

184. Ibid, para 39.

185. J Gans and A Leigh Did the Death of Australian Inheritance Taxes Affect Deaths? (June 2006), available at http://papers.ssrn.com/sol3/papers.cfm?abstract_id=907250.

186. W Pedrick 'Oh! To die Down Under! Abolition of death and gift duties in Australia' (1981) 35 Tax Lawyer 113 at 114. Farming communities consistently complained that farms had to be sold in order to pay death duties. Of course, the same complaint could be made in respect of family businesses.

187. Duff, above $n 181$, at 74 .

188. Ibid. at 108-109. 
The ease with which Sweden abandoned its inheritance and gift tax at the beginning of 2005 suggests that there must have been overwhelming political support for the measure, perhaps an indication of the high political cost of retaining an unpopular tax. In its proposal to Parliament for the abolition of the tax, the government stated:

'The Inheritance and Gift Tax (IGT) has been the subject of sharp criticism in recent years. The argument has centred on the difficulties experienced by surviving spouses and partners in paying the increasing levels of IHT that follows from the increased tax valuations of real property ... The levying of IGT in connection with transfers of small businesses to the next generation has also been criticised. Following the fall in the stock market in 2000 , there have been demands for a change in the IHT in relation to equities and other forms of investment. The opportunities for tax planning have also been criticised. Due to the regulatory framework applicable to valuation, it has been possible to legally significantly decrease the IGT due. The tax is not perceived as fair. The Government does not consider it possible to address the criticism against IGT by modifying the regulatory framework. In addition, the administrative framework surrounding the inheritance and gift tax is relatively costly. The tax is calculated to provide an income of 2.6 billion SEK ${ }^{189}$ for $2004 \ldots$. $^{190}$

It is submitted that, whilst it is difficult to draw on any similarities between the impetus for abolition in Canada with that in the UK, such similarities do exist with both Australia and Sweden. Of the three factors suggested by Duff which led to the abolition of Australia's death and gift duties, two are identical to those currently existing in the UK, namely that exemptions and, in the case of the UK, the threshold, has not kept up with inflation, and that the tax is easily avoided by those with wealth enough to be able to afford to do so. Similarly, property prices and avoidance were the reasons given by the Swedish government in their proposal for abolition of the IGT. These factors suggest that a call to abolish IHT in the UK is not quite as farfetched as some would imagine, particularly bearing in mind that tax revenues on property in the UK, amounting to $4.0 \%$ of gross domestic product, are the highest of all the Organisation for Economic Cooperation and Development countries including those of the European Community. ${ }^{191}$ Whilst it is easy to say that it is not wholly unsurprising that a right-wing Australian government might be expected to abolish the tax, such a statement could not be made of Sweden and its social democratic government. Sweden has been able to abolish the IGT even though its public service provision is reputedly far superior to that in the UK, ${ }^{192}$ although it should be mentioned that Sweden continues to impose on its citizens an annual wealth tax that previously co-existed with the IGT.

189. Swedish Krona.

190. (2004) 15(25) Prop 22. I am indebted to Johanna Hjalmarsson, Institute of Maritime Law, School of Law, University of Southampton, for her help in accessing this material and for translating from Swedish into English.

191. See I Joumard Tax Systems in European Countries OECD Economics Department Working Papers, No 301 (ECO/WKP (2001)27, 2001) p 27. The percentage is likely to be greater in forthcoming years, with the revaluation of homes for council tax purposes and the increase in that tax for many people.

192. For example, in 2000, Sweden's age-related spending amounted to $29.0 \%$ of gross domestic product compared with the UK's $15.6 \%$; see ibid, p 8 . 


\section{CONCLUSION}

The history of death duties reveals a tax that, when introduced in 1884 as estate duty, was not only significant for its yield, but one that was also perceived as a more popular form of taxation in comparison to the alternatives, if any tax could ever be described as popular. The current situation could not be more different. According to the various polls, IHT is far from a popular tax. ${ }^{193}$ Importantly, arguments rooted in equity and based on the notion of redistribution of wealth seem to be unfounded. Not only is IHT unfair, with the very wealthy having the ability and wherewithal to avoid it, leaving the burden to fall on those with only modest wealth but, unsurprisingly given that the wealthiest are failing to pay their true share, the imposition of the various estates taxes over the years (estate duty, CTT and IHT) would appear to have failed to bring about a change in wealth ownership. In the absence of a policy amounting to a confiscation of inheritances in order to reduce the inequality in wealth, which would be politically unsustainable, it seems that an estate tax in the form of IHT cannot truly contribute in any meaningful way to a redistribution of wealth.

This conclusion suggests that, at the very least, IHT should be reformed. Of the suggested reform measures referred to above, the most viable one is simply to increase 'the ludicrously low nil-rate band' ${ }^{194}$ the other option of exempting the main residence altogether from IHT might cause an unwelcome investment imbalance by encouraging individuals to invest more money in their homes rather than in other more useful assets.

However, in addition to the issues of fairness, the economic analysis has shown that the tax is not a particularly efficient one. Even if the argument that the imposition of IHT tends to reduce savings is tenuous, there appear to be no compelling economic arguments for the continued existence of IHT; indeed, it has been shown that the tax actually imposes extra burdens, often to the detriment of older members of society and possibly to businesses. As far as yield is concerned, although the $£ 3.56$ billion raised from IHT is a significant increase in comparison to even a few years ago, it is still a drop in the ocean when viewed in the context of total HMRC tax revenues of $£ 424.38$ billion. ${ }^{195}$ And the yield becomes even less significant when the costs of collection are factored into the equation. ${ }^{196}$ Nor should compliance costs be overlooked: the tax has become so complex, particularly following the major amendments made by the Finance Act 2006, that taxpayers almost inevitably need the assistance of professional advisers when drafting their wills.

IHT fails to satisfy the criteria for an equitable tax and appears to be economically inefficient. Other countries have seen fit to dispense with their estates taxes. It is submitted that the case has been made for the abolition of IHT. Reforming the system would merely be tampering with a structure that, at its root, is overly complex and unfair, and would do little to overcome the economic inefficiency discussed above.

193. See above $\mathrm{n} 90$.

194. Per Lord Burnett Hansard HL Deb, vol 869, col 452.

195. HMRC, above $\mathrm{n} 152$.

196. To those who say that, although only a drop in the ocean, the revenues from IHT cannot simply be overlooked, it has already been argued that there are perfectly viable alternative means of raising the revenue that would be lost through the abolition of the tax. 